\title{
Antibacterial activity of synthetic analogues based on the disaccharide structure of moenomycin, an inhibitor of bacterial transglycosylase
}

Advanced Medicine East Inc., 8 Clarke Drive, Cranbury, NJ 08512, USA

\author{
Eugene R. Baizman, Arthur A. Branstrom, Clifford B. Longley, \\ Nigel Allanson, $\uparrow$ Michael J. Sofia, $\ddagger$ David Gange \\ and Robert C. Goldman $\mathbb{S}$
}

Author for correspondence: Eugene R. Baizman. Tel: +1609655 6925. Fax: +1 6096556930. e-mail: ebaizman@advmedicine.com
Moenomycin is a natural product glycolipid that inhibits the growth of a broad spectrum of Gram-positive bacteria. In Escherichia coli, moenomycin inhibits peptidoglycan synthesis at the transglycosylation stage, causes accumulation of cell-wall intermediates, and leads to lysis and cell death. However, unlike Esc. coli, where 5-6 log units of killing are observed, 0-2 log units of killing occurred when Gram-positive bacteria were treated with similar multiples of the MIC. In addition, bulk peptidoglycan synthesis in intact Gram-positive cells was resistant to the effects of moenomycin. In contrast, synthetic disaccharides based on the moenomycin disaccharide core structure were identified that were bactericidal to Gram-positive bacteria, inhibited cell-wall synthesis in intact cells, and were active on both sensitive and vancomycinresistant enterococci. These disaccharide analogues do not inhibit the formation of $\boldsymbol{N}$-acetylglucosamine- $\beta$-1,4-MurNAc-pentapeptide-pyrophosphorylundecaprenol (lipid II), but do inhibit the polymerization of lipid II into peptidoglycan in Esc. coli. In addition, cell growth was required for bactericidal activity. The data indicate that synthetic disaccharide analogues of moenomycin inhibit cell-wall synthesis at the transglycosylation stage, and that their activity on Gram-positive bacteria differs from moenomycin due to differential targeting of the transglycosylation process. Inhibition of the transglycosylation process represents a promising approach to the design of new antibacterial agents active on drug-resistant bacteria.

Keywords: moenomycin, peptidoglycan synthesis, transglycosylation

\section{INTRODUCTION}

Bacterial peptidoglycan synthesis initiates in the cytoplasm with the synthesis of UDP- $\mathrm{N}$-acetyl-muramyl-pentapeptide (UDP-MurNAc-pentapeptide). The MurNAc-pentapeptide is transferred via the mraY gene product to a C55 undecaprenol phosphate carrier lipid

\footnotetext{
†Present address: PanTherix Ltd, Unit 6.10, Kelvin Campus, Maryhill Rd, Glasgow G20 OSP, UK.

‡Present address: Bristol-Myers Squibb Pharmaceutical Research Institute, PO Box 5100, Wallingford, CT 06392-7660, USA.

\$Present address: National Institutes of Health, NIAID, DEA, Bethesda, MD 20892, USA.
}

generating MurNAc-pentapeptide-pyrophosphorylundecaprenol (lipid I). N-Acetylglucosamine is then transferred from UDP-N-acetylglucosamine (UDPGlcNAc) to lipid I via MurG, generating $N$-acetylglucosamine- $\beta$-1,4-MurNAc-pentapeptide-pyrophosphoryl-undecaprenol (lipid II). Lipid II is then polymerized into peptidoglycan by specific transglycosylases. These enzymes can be bifunctional, containing associated transpeptidase activity (e.g. PBP1A, PBP1B and PBP1C) or monofunctional (product of the $m t g$ gene). Note that the monofunctional glycosyltransferase was referred to as mgt (Di Berardino et al., 1996), but that this designation is used in the genome databases for the $\mathrm{Mg}^{2+}$ transport system, also referred to as $\operatorname{cor} A$. It now appears that databases are listing the 


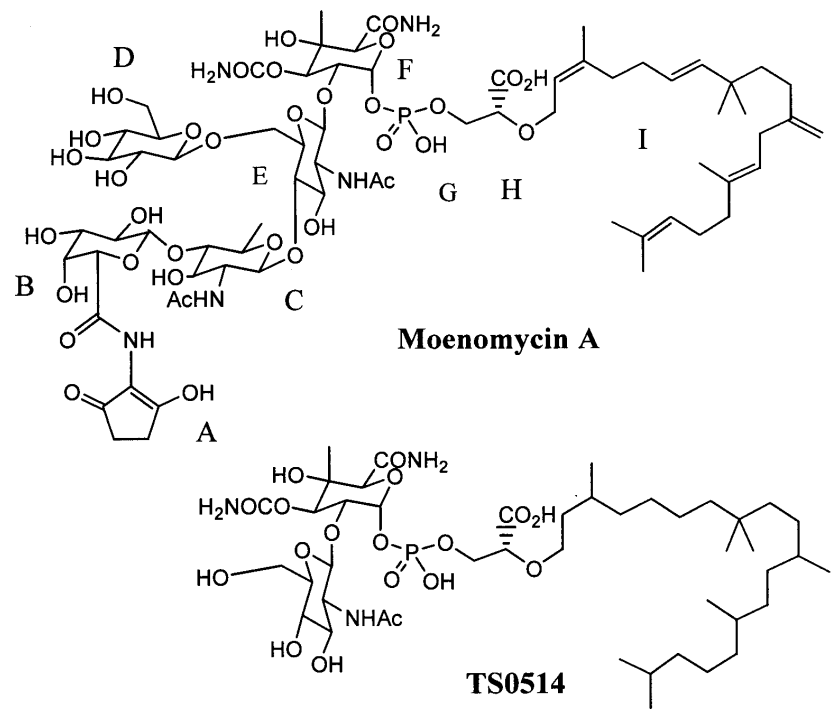

Fig. 1. Structure of moenomycin $A$ and its disaccharide degradation product TS0514. The various structural units of moenomycin referred to in the text are labelled A-I.

monofunctional glycosyltransferase as $m \operatorname{tg} A$. This pathway in Escherichia coli was recently reviewed (Holtje, 1998).

Moenomycin is a natural product inhibitor of bacterial peptidoglycan synthesis, acting at the stage of transglycosylation. Structurally it consists of a pentasaccharide chain linked to a $\mathrm{C}_{25}$ hydrophobic tail, moenocinol, via a phosphoric acid diester and a glycerol acid unit (Fig. 1). Degradation studies reveal that some of the structural elements present in the parent molecule can be removed with retention of varying degrees of biological activity (for review see El-Abadla et al., 1999). Although trisaccharide analogues of moenomycin are potent inhibitors of the in vitro transglycosylation reaction in Escherichia coli, they are 50-fold less active as antibacterial agents against Staphylococcus aureus (El-Abadla et al., 1999). In contrast, specific disaccharide analogues maintain the ability to inhibit Esc. coli transglycosylase activity in vitro, while losing almost all (> 500-fold against Sta. aureus, and at least 700-fold against Streptococcus pyogenes) antibacterial activity (El-Abadla et al., 1999).

Esc. coli is the only organism used thus far in the study of the precise mechanism of antibacterial activity of moenomycin and its analogues. Moenomycin inhibits the in vitro transglycosylation reaction in Esc. coli (van Heijenoort et al., 1978; van Heijenoort \& van Heijenoort, 1980) where the main cell-wall polymerization and cross-linking activity is due to penicillinbinding protein (PBP) 1B. The activity of PBP1A (and arguably PBP3; Goffin \& Ghuysen, 1998; Adam et al., 1997) may also be sensitive to moenomycin-like inhibitors (Ishino \& Matsuhashi, 1981; Matsuhashi et al., 1981), as may PBP1C (Schiffer \& Holtje, 1999), but these data are not as definitive as the data for inhibition of PBP1B. In any event, moenomycin does not appear to inhibit the monofunctional transglycosylase from Esc. coli (Di Berardino et al., 1996). Although moenomycin is not as potent against Esc. coli compared to Grampositive organisms (due to the outer-membrane barrier), its mode of action on whole cells is consistent with inhibition of cell-wall synthesis. Moenomycin causes rapid lysis of growing Esc. coli cells (van Heijenoort et al., 1987), but not stationary-phase cells. Lysis, but not killing, was inhibited by the addition of $\mathrm{Mg}^{2+}$, consistent with the functioning of the autolytic system in Esc. coli. UDP-MurNAc-pentapeptide and the lipid-linked precursors lipid I and II accumulated when Esc. coli was treated with moenomycin (Kohlrausch \& Holtje, 1991a). All of these data with Esc. coli are consistent with the hypothesis that inhibition of transglycosylation leads to growth inhibition and killing even in the absence of lysis.

Much less is known about the effects of moenomycin on Gram-positive organisms. Given the poor activity of moenomycin on Esc. coli compared to Gram-positive bacteria, it seems likely that moenomycin evolved as an inhibitor of the much more sensitive Gram-positive organisms. Moenomycin does induce the vancomycinresistance pathway in Enterococcus faecalis (Mani et al., 1998) and Enterococcus faecium (Lai \& Kirsch, 1996), consistent with inhibition of cell-wall synthesis; however, there are few additional data on the biochemical and physiological consequence of exposure of Grampositive organisms to moenomycin.

There is a growing need for new antibacterial agents that are active on drug-resistant Gram-positive pathogens. Our effort to discover novel analogues of moenomycin prepared by combinatorial synthesis (Kakarla et al., 1999; Sofia et al., 1999) led to identification of several related disaccharide analogues with unique antibacterial properties. Synthetic disaccharide analogues were identified that: (1) were bactericidal for Gram-positive organisms; (2) were active against antibiotic-resistant bacteria (including vancomycinresistant enterococci); (3) killed growing, but not stationary-phase cells; and (4) inhibited peptidoglycan synthesis in intact Ent. faecalis cells.

\section{METHODS}

Strains and growth conditions. Esc. coli ATCC 23226 was grown aerobically at $37^{\circ} \mathrm{C}$ in a $10 \mathrm{l}$ fermenter in Brain Heart Infusion medium (BHI) supplemented with $0 \cdot 1 \%(\mathrm{w} / \mathrm{v})$ Casamino acids (BHI/CAA) plus $1 \%(\mathrm{w} / \mathrm{v})$ glucose. The culture was grown exponentially to an $\mathrm{OD}_{600}$ value of $6(1 \mathrm{~cm}$ cell, Perkin Elmer Lambda 2S spectrophotometer) using aeration $\left(11 \mathrm{~min}^{-1}\right)$ with air/oxygen to maintain a dissolved $\mathrm{O}_{2}$ concentration of $5 \%$. The $\mathrm{pH}$ was maintained at 6.5 . The culture was then cooled on ice, harvested by centrifugation at $6000 \mathrm{~g}$ for $20 \mathrm{~min}$, and the cell pellet was stored at $-80^{\circ} \mathrm{C}$. Cells were used for synthesis of peptidoglycan following permeabilization with ether as described below.

Esc. coli OV58 (pTA9) overexpressing MurG (Ikeda et al., 1992) was grown to an $\mathrm{OD}_{600} 1.0$ at $37^{\circ} \mathrm{C}$ in a $10 \mathrm{l}$ batch fermenter in $\mathrm{BHI} / \mathrm{CAA}$ using $11 \mathrm{~min}^{-1}$ aeration with air and 150 r.p.m. agitation. The $\mathrm{pH}$ was not controlled. The cells 
were chilled on ice and harvested by centrifugation at $6000 \mathrm{~g}$ for $20 \mathrm{~min}$. Cells were washed once with $5 \mathrm{mM}$ Tris/HCl, $\mathrm{pH} 8.0\left[50 \mathrm{ml}(\mathrm{g} \text { wet pellet } \mathrm{wt})^{-1}\right]$, then resuspended in the same buffer to a concentration of $0.06 \mathrm{~g}$ wet wt ml-1. Membranes were prepared following lysis of cells at 20000 p.s.i. (138 MPa) with a French press. The lysate was centrifuged at $6000 \mathrm{~g}$ for $10 \mathrm{~min}$, and the resulting supernatant was ultracentrifuged at $200000 \mathrm{~g}$ for $1 \mathrm{~h}$. The pellet was resuspended in assay buffer and used as a source of enzymes for evaluation of lipid II formation (see below).

Determination of MIC values. The MIC of test compounds was determined in 96-well microtitre plates using twofold dilutions in BHI/CAA medium. Exponentially growing cells were diluted to approximately $5 \times 10^{5}$ c.f.u. $\mathrm{ml}^{-1}$ and subjected to test compounds solubilized and serially diluted in DMSO. At a final concentration of $5 \%(\mathrm{v} / \mathrm{v})$, DMSO had no effect on cell growth or viability. Following an $18 \mathrm{~h}$ incubation at $37^{\circ} \mathrm{C}$, the $\mathrm{OD}_{600}$ values were read on a microplate reader (Dynatec, model MR5000) immediately after plate mixing. The MIC was determined using the following criteria: $\left(\mathrm{OD}_{600}\right.$ untreated cells $-\mathrm{OD}_{600}$ test concentration $) /\left(\mathrm{OD}_{600}\right.$ untreated cells $-\mathrm{OD}_{600}$ media blanks) $\times 100 \geqslant 90 \%$.

Determination of bactericidal activity. Cells were grown in $\mathrm{BHI} / \mathrm{CAA}$ at $37^{\circ} \mathrm{C}$ and test compounds were added to exponentially growing cells $\left(\mathrm{OD}_{600} 0 \cdot 08-0 \cdot 1\right)$. Samples were incubated with shaking at $37^{\circ} \mathrm{C}$ for $4 \mathrm{~h}$, and viable cells determined over time by plating a dilution series in triplicate onto $\mathrm{BHI} / \mathrm{CAA}$ agar plates that were incubated at $37^{\circ} \mathrm{C}$ for $18-36 \mathrm{~h}$ prior to counting. Bactericidal activity was also determined using stationary cells prepared by overnight growth in BHI/CAA. Cell growth was shut off with either chloramphenicol $\left(50 \mu \mathrm{g} \mathrm{ml}^{-1}\right)$, tetracycline $\left(20 \mu \mathrm{g} \mathrm{ml}^{-1}\right)$ or moenomycin $\left(10 \mu \mathrm{g} \mathrm{ml}^{-1}\right)$ added to the culture. Viable counts were determined at the time of growth shut-off, then challenge compounds were added. Viable bacteria remaining after a $4 \mathrm{~h}$ incubation at $37^{\circ} \mathrm{C}$ with shaking were determined by plating for c.f.u.

Preparation of ether permeabilized Esc. coli cells. Esc. coli ATCC 23226 cells were exposed to diethyl ether as described (Mirelman et al., 1976; Vosberg \& Hoffmann-Berling, 1971) with minor modifications. Frozen bacterial cell pellets (grown and harvested as described above) were thawed on ice, washed twice by centrifugation ( $8000 \mathrm{~g}$ for $10 \mathrm{~min}$ ) in Basic Medium (Vosberg \& Hoffmann-Berling, 1971), then permeabilized by a $1 \mathrm{~min}$ ether treatment. Cell suspensions were stored at $-80^{\circ} \mathrm{C}$ in the presence of DMSO $(1 \%, \mathrm{v} / \mathrm{v})$ in $1 \mathrm{ml}$ aliquots of $5-10 \mathrm{mg}$ protein $\mathrm{ml}^{-1}$. A new aliquot was thawed immediately prior to use for each assay, washed with and resuspended in peptidoglycan polymerization assay buffer (see below).

Purification of UDP-MurNAc-pentapeptide from bacteria. Ent. faecium strain MT10 Rev (Billot-Klein et al., 1997), or Bacillus cereus ATCC 11778 was grown aerobically in a 101 fermenter in BHI/CAA medium. The substrate UDPMurNAc-pentapeptide, containing either L-lysine or mesodiaminopimelic acid, was isolated from these cells as described (Kohlrausch \& Holtje, 1991b), with minor modifications. The concentration of purified nucleotide sugars was determined using the molar extinction coefficient of uridine, $\varepsilon_{\mathrm{M}, 262}=$ $1 \times 10^{4}$. The UDP-MurNAc-pentapeptides were authenticated by mass spectrometry, and lyophilized for storage at $-80^{\circ} \mathrm{C}$.

Biotin labelling of UDP-MurNAc-pentapeptide. UDPMurNAc-pentapeptide (containing L-lysine) was labelled (Men et al., 1998) using solid sulfo-NHS-LC Biotin (Pierce). The UDP-MurNAc-pentapeptide-biotin conjugate was puri- fied by HPLC using a Supelcosil C-18 $\quad(4.6 \mathrm{~mm} \times 25 \mathrm{~cm})$ column eluted at $1.0 \mathrm{ml} \mathrm{min}{ }^{-1}$ with an elution profile of potassium phosphate $(10 \mathrm{~min})$, water $(5 \mathrm{~min})$, followed by a $30 \mathrm{~min}$ linear gradient to $50 \%$ methanol/water $(\mathrm{v} / \mathrm{v})$ (Branstrom et al., 2000b).

Peptidoglycan polymerization assay. Peptidoglycan synthesis was determined in ether-treated bacteria (ETB) as described (Allen et al., 1992, 1996), with modifications for adaptation to automated liquid handing equipment. GFC filter-bottom 96well microplates (Millipore) were used throughout. Assay buffer was prepared fresh daily from $10 \times$ stock solutions, and contained: $50 \mathrm{mM}$ Tris $/ \mathrm{HCl}(\mathrm{pH} 8.3) ; 50 \mathrm{mM} \mathrm{NH} \mathrm{NH}_{4} \mathrm{Cl}$; $20 \mathrm{mM} \mathrm{MgSO}{ }_{4} ; 0.15 \mathrm{mM}$ D-aspartic acid, $100 \mu \mathrm{g}$ tetracycline $\mathrm{ml}^{-1}$ and $0.5 \mathrm{mM} \beta$-mercaptoethanol (reagents from Sigma Chemical). Reaction mixtures $(100 \mu \mathrm{l})$ also contained: $5 \mathrm{mM}$ ATP (Tris salt), $1.0 \mu \mathrm{M}$ UDP-N-acetyl- $\left[{ }^{14} \mathrm{C}\right] \mathrm{D}-$ glucosamine [UDP-GlcNAc, DuPont/NEN or Amersham; 200-300 $\left.\mathrm{mCi}(7 \cdot 4-11 \cdot 1 \mathrm{GBq}) \mathrm{mmol}^{-1}\right]$, and 15-25 $\mu \mathrm{M}$ UDPMurNAc-pentapeptide (containing meso-diaminopimelic acid). Assay buffer $(10 \mu \mathrm{l})$, ATP $(20 \mu \mathrm{l})$, UDP-MurNAcpentapeptide $(10 \mu \mathrm{l})$ and $\mathrm{UDP}-\left[{ }^{14} \mathrm{C}\right] \mathrm{GlcNAc}(20 \mu \mathrm{l})$ were mixed and added as a single $60 \mu \mathrm{l}$ aliquot to all wells with a Tecan Genesis 150 liquid handler, followed by either $20 \mu$ test compound, reference standard or buffer/vehicle. Reactions were initiated by adding $20 \mu \mathrm{l}$ ETB suspension $(25-30 \mu \mathrm{g}$ bacterial protein well ${ }^{-1}$ ). Plates were covered, mixed and incubated for $120 \mathrm{~min}$ at $37^{\circ} \mathrm{C}$. A $100 \mu \mathrm{l}$ aliquot of ice-cold $20 \%(\mathrm{w} / \mathrm{v})$ TCA was added to terminate the reaction, and plates were held at $4{ }^{\circ} \mathrm{C}$ for $30 \mathrm{~min}$ to ensure complete precipitation of peptidoglycan. Each plate was then filtered under vacuum and washed rapidly 5-6 times with $200 \mu 110 \%$ $(\mathrm{w} / \mathrm{v})$ ice-cold TCA. A $30 \mu \mathrm{l}$ aliquot of Optiphase Supermix (EG \& G Wallac) was added to each well for overnight equilibration and plates were counted in a Microbeta Trilux LSC (model 1450; EG \& G Wallac). Reaction blanks were defined as corrected c.p.m. retained on the filter either in the absence of UDP-MurNAc-pentapeptide or in the presence of a concentration of reference compound (moenomycin) completely suppressing incorporation of radiolabel. Concentration-response curves were analysed by non-linear regression using a four-parameter logistic model fitted and plotted with GraphPad Prism (v. 2.01, GraphPad Software). $\mathrm{IC}_{50}$ values given in the text represent means from 2-10 separate experiments, each curve using at least 5-7 concentrations of test compound in duplicate wells.

Effect of drugs on peptidoglycan degradation. The stability of peptidoglycan made during various time periods of the reaction using ether permeabilized Esc.coli cells was examined in the presence of the disaccharide analogues. Reactions were set as given above, and initiated by addition of warmed ether permeabilized cells $(20 \mu \mathrm{l}, 30 \mu \mathrm{g}$ protein per well) to all reaction wells. Vehicle or test compound $(20 \mu \mathrm{l})$ was then added sequentially to appropriate wells at $t_{0}(120 \mathrm{~min}$ incubation with drug), $t_{30}$ min (90 min incubation with drug), $t_{60} \min \left(60 \mathrm{~min}\right.$ incubation with drug), $t_{90} \mathrm{~min}(30 \mathrm{~min}$ incubation with drug) and $t_{120} \mathrm{~min}(0 \mathrm{~min}$ incubation with drug). At $t_{120}$ min, reactions were terminated by addition of $100 \mu 120 \%$ (w/v) TCA to all wells, followed by shaking for $30 \mathrm{~s}$ on an orbital plate shaker. Samples were then processed (see above) and radioactivity incorporated into peptidoglycan determined as described above.

Peptidoglycan synthesis in intact cells. Ent. faecalis ATCC 29212 was grown in BHI/CAA medium at $37^{\circ} \mathrm{C}$ and used to measure incorporation of radiolabelled lysine into peptidoglycan as described by Allen et al. (1996) with minor modifications for adaptation to microtitre filtration. Briefly, 
this involved treatment of cells with $50 \mu \mathrm{g}$ tetracycline $\mathrm{ml}^{-1}$ plus $100 \mu \mathrm{g}$ chloramphenicol ml $\mathrm{m}^{-1}$ for $30 \mathrm{~min}$ to inhibit protein synthesis. Varying concentrations of drugs were added to cells, and reactions were initiated by addition of $\left[{ }^{14} \mathrm{C}\right] \mathrm{L}$-lysine $\left[0 \cdot 25 \mu \mathrm{Ci}(9 \cdot 25 \mathrm{kBq})\right.$ per reaction, $329 \mathrm{mCi}\left(12 \cdot 2 \mathrm{GBq}^{2} \mathrm{mmol}^{-1}\right.$; Amersham]. Reactions were stopped, samples processed and data analysed as described above for the peptidoglycan polymerization assay. Incorporation was linear for $60 \mathrm{~min}$, and 15000-20000 d.p.m. were incorporated into control samples.

Inhibition of transglycosylation and accumulation of lipid intermediates. Inhibition of mature (cross-linked) and immature (nascent) peptidoglycan, and accumulation of lipid intermediates was determined as described (Ge et al., 1999). Briefly, this method uses $1.0 \mathrm{mg}$ penicillin $\mathrm{G} \mathrm{ml}^{-1}$ to inhibit cross-linking of peptidoglycan into mature strands, and follows accumulation of lipid intermediates by extraction into butanol-pyridinium acetate.

Lipid II formation assay. The assay was performed as described by Branstrom et al. (2000b). Reaction components consisted of bacterial membranes ( $25 \mu \mathrm{g}$ protein), $0.5 \mu \mathrm{M}$ UDP$\left[{ }^{14} \mathrm{C}\right]$ GlcNAc $[\approx 20000$ d.p.m. (333 Bq)], $10 \mu \mathrm{M}$ biotinylated UDP-MurNAc-pentapeptide and $0 \cdot 1 \%(\mathrm{v} / \mathrm{v})$ Triton X-100, all in $50 \mu \mathrm{l}$ assay buffer $(50 \mathrm{mM}$ Tris $/ \mathrm{HCl}, \mathrm{pH} 8.0,42 \mathrm{mM}$ $\mathrm{Mg}(\mathrm{Ac})_{2}$ and $\left.208 \mathrm{mM} \mathrm{KCl}\right)$. Reactions were preincubated without radiolabelled UDP-GlcNAc for $10 \mathrm{~min}$ at room temperature to allow formation of lipid I and then lipid II formation was initiated by addition of UDP-GlcNAc. Lipid II synthesis was allowed to proceed for $15 \mathrm{~min}$ at room temperature before being terminated with $25 \mu \mathrm{l} 1 \%(\mathrm{w} / \mathrm{v})$ SDS. Incorporation of labelled GlcNAc continued for 40$50 \mathrm{~min}$ in control reactions. Lipid II was identified by mobility using paper chromatography (van Heijenoort et al., 1992) and specific capture with Softlink avidin resin (Promega) (see below).

Streptavidin-bead capture. Capture of biotinylated lipid II was as previously described by Branstrom et al. (2000b). Binding buffer $(10 \mathrm{mM}$ Tris/ $\mathrm{HCl}, \mathrm{pH} 8 \cdot 0,150 \mathrm{mM} \mathrm{NaCl}$, $0 \cdot 2 \% \mathrm{v} / \mathrm{v}$ Triton $\mathrm{X}-100)$ either $500 \mu \mathrm{l}$ or $100 \mu \mathrm{l}$, was added to Eppendorf tubes or 96-well filter plates, respectively, containing lipid II reaction mixtures. Tetralink (Promega) tetrameric avidin resin $(35 \mu \mathrm{l}$ as supplied) was added to each reaction to allow for capture of product. For the tube assay, samples were gently mixed for $1 \mathrm{~h}$ at room temperature, centrifuged for $3 \mathrm{~min}$ at $1500 \mathrm{~g}$, and then washed four times with $500 \mu \mathrm{l}$ binding buffer. Reactions run in filter plates were vacuum filtered and washed five times with $200 \mu \mathrm{l}$ binding buffer. The washed beads from Eppendorf tubes were resuspended in buffer, mixed with scintillation cocktail, and counted in a scintillation counter to determine the amount of lipid II product made. Softlink monomeric avidin resin (Promega) was substituted for Tetralink resin when the captured product needed to be released for further analysis by paper chromatography (Anderson et al., 1966).

Polymerization of lipid II into peptidoglycan. Polymerization of lipid II into peptidoglycan was monitored in situ (Branstrom et al., 2000a). The first step of this assay allowed synthesis and accumulation of lipid II in a reaction mixture containing Esc. coli membranes $\left(0.5 \mathrm{mg} \mathrm{ml}^{-1}\right)$, UDP-MurNAc pentapeptide $(20 \mu \mathrm{M})$ and radiolabelled UDP-GlcNAc $(0.5 \mu \mathrm{M})$ in reaction buffer $\left(50 \mathrm{mM}\right.$ Tris; $\mathrm{pH} \mathrm{8.0;} 42 \mathrm{mM} \mathrm{Mg}(\mathrm{Ac})_{2} ; 208 \mathrm{mM} \mathrm{KCl}$; $0 \cdot 1 \% \mathrm{v} / \mathrm{v}$ Triton X-100; and $10 \% \mathrm{v} / \mathrm{v}$ DMSO). Reactions were incubated for $2 \mathrm{~h}$ at room temperature to accumulate endogenous lipid II. Inhibitors were added prior to removal of Triton X-100 by the addition of Detergent-Out resin (Geno-
Technology). Reactions proceeded for an additional $2 \mathrm{~h}$ at room temperature to allow conversion of lipid II into peptidoglycan, which was monitored by ascending paper chromatography (Anderson et al., 1966).

Effect on Candida albicans growth and glucan synthesis. Candida albicans strain CCH442 was grown in BHI/CAA to $\mathrm{OD}_{600} 0 \cdot 1$, and drugs added. Growth and viable counts were monitored. Microsomes were prepared as previously described for assay of 1,3- $\beta$-glucan synthesis (Frost et al., 1994), monitoring incorporation of $\left[{ }^{14} \mathrm{C}\right]$ glucose from UDPglucose into glucan.

In vitro cytotoxicity. $\mathrm{LD}_{50}$ values for cytotoxicity of moenomycin and the synthetic disaccharide analogues were determined in three mammalian cell lines - NIH3T3, HL-60 and HBL-100. Test compounds diluted in OptiMEM (Gibco$\mathrm{BRL}$ ), or medium alone were incubated for $6 \mathrm{~h}$ at $37^{\circ} \mathrm{C}$. Medium was removed and cells were incubated with fresh medium for $18 \mathrm{~h}$. A Cytolux (EG \& G Wallac) luminescent assay kit and Wallac Trilux plate reader were used to screen for cell viability as described by the manufacturer. At least eight concentrations of test compound were used to determine the $\mathrm{LD}_{50}$ computed by a four-parameter logistic fit of percentage cell viability versus drug concentration.

Antibiotics. Moenomycin A was isolated and purified by standard preparative HPLC from commercial sources (Flavomycin; Hoechst). Reference standard antibiotics were purchased from Sigma. All synthetic disaccharide analogues were prepared at Incara Research Laboratories as described by Sofia et al. (1999).

\section{RESULTS}

\section{Antibacterial activity of moenomycin analogues}

Moenomycin possesses potent antibacterial activity against Gram-positive bacteria, but is much less active against Gram-negative bacteria (van Heijenoort et al., 1987). However, moenomycin is quite active against Esc. coli BAS849, containing a defect in outer-membrane structure (Table 1). This strain of Esc. coli was isolated as a mutant hypersuseptible to antibiotics (Sampson et al., 1989). The disaccharide product of moenomycin degradation, TS0514 (Fig. 1), was devoid of antibacterial activity (MIC $>100 \mu \mathrm{g} \mathrm{ml}^{-1}$ ) as reported by El-Abadla et al. (1999; see p. 706 therein) in their later assays.

Starting with the basic lipid-linked disaccharide moenomycin core, we initiated a programme to produce synthetic disaccharide analogues that regained antibacterial activity. Analogues TS30153, TS30663 and TS30888 (Fig. 2) are related in structure to the moenomycin E-F disaccharide TS0514 (Fig. 1). All contain a lipid anchor $\left(\mathrm{C}_{12}\right.$ lipid), and possess a $\beta$-linked disaccharide similar to the moenomycin E-F disaccharide. They differ from the moenomycin disaccharide by the substitution of a nitrogen functionality in place of the C-3 oxygen of moenomycin and the absence of the C-4 methyl group of the F-sugar. In addition, TS30153 replaces the moenomycin glucosamine E-unit with a galactosamine sugar. All contain aromatic moieties attached to the saccharide units (units E and F, see Figs 1 and 2). The disaccharide analogues were active on Gram-positive bacteria (Table 1) and two showed 
Table 1. MIC values $\left(\mu \mathrm{g} \mathrm{ml}^{-1}\right)$ for moenomycin analogues and reference compounds

MICs were determined by microbroth dilution in BHI/CAA media on two or more occasions, and were identical or within twofold.

Note: TS30153, TS30663 and TS30888 are given as compounds 23, 21 and 18, respectively, by Sofia et al. (1999). MIC values for TS0514 (moenomycin disaccharide degradation product) on these strains was $>100 \mu \mathrm{g} \mathrm{ml}^{-1}$ (from El-Abadla et al., 1999).

\begin{tabular}{|c|c|c|c|c|c|c|c|c|c|}
\hline Compound & $\begin{array}{l}\text { Esc. coli } \\
\text { BAS } 849^{*}\end{array}$ & $\begin{array}{c}\text { Ent. } \\
\text { faecalis } \\
\text { ATCC } \\
29212\end{array}$ & $\begin{array}{c}\text { Ent. } \\
\text { faecium } \\
\text { ATCC } \\
49624\end{array}$ & $\begin{array}{c}\text { Sta. } \\
\text { aureus } \\
\text { ATCC } \\
29213\end{array}$ & $\begin{array}{c}\text { Sta. } \\
\text { epidermidis } \\
\text { ATCC } \\
12228\end{array}$ & $\begin{array}{c}\text { Ent. } \\
\text { faecalis } \\
\text { CL4877 } \\
\text { (VanB) }\end{array}$ & $\begin{array}{c}\text { Ent. } \\
\text { faecalis } \\
\text { CL5244 } \\
\text { (VanB) }\end{array}$ & $\begin{array}{c}\text { Ent. } \\
\text { faecium } \\
\text { RLA1† }\end{array}$ & $\begin{array}{c}\text { Ent. } \\
\text { faecium } \\
\text { CL4931 } \\
\text { (VanA) }\end{array}$ \\
\hline TS30153 & $>25$ & $6 \cdot 25$ & $6 \cdot 25$ & $6 \cdot 25$ & $6 \cdot 25$ & $3 \cdot 13$ & $6 \cdot 25$ & $12 \cdot 5$ & $6 \cdot 25$ \\
\hline TS30663 & $12 \cdot 5$ & $6 \cdot 25$ & $6 \cdot 25$ & $6 \cdot 25-12 \cdot 5$ & $6 \cdot 25-12 \cdot 5$ & $3 \cdot 13$ & $3 \cdot 13$ & $6 \cdot 25$ & $6 \cdot 25$ \\
\hline TS30888 & 25 & $12 \cdot 5$ & $12 \cdot 5$ & $12 \cdot 5$ & $12 \cdot 5$ & $6 \cdot 25$ & $12 \cdot 5$ & & 25 \\
\hline Vancomycin & $0 \cdot 78-1 \cdot 56$ & $3 \cdot 12$ & $0 \cdot 39$ & $1 \cdot 56$ & $1 \cdot 56$ & 1250 & $15-25$ & $0 \cdot 78$ & $>1250$ \\
\hline Moenomycin & $0 \cdot 025$ & 0.078 & $>200$ & $0 \cdot 05$ & $0.025-0.05$ & $0 \cdot 13$ & 0.06 & 0.78 & $0 \cdot 25$ \\
\hline
\end{tabular}

*Strain BAS 849 is supersensitive to antibiotics.

†Strain RLA1 is ampicillin resistant.
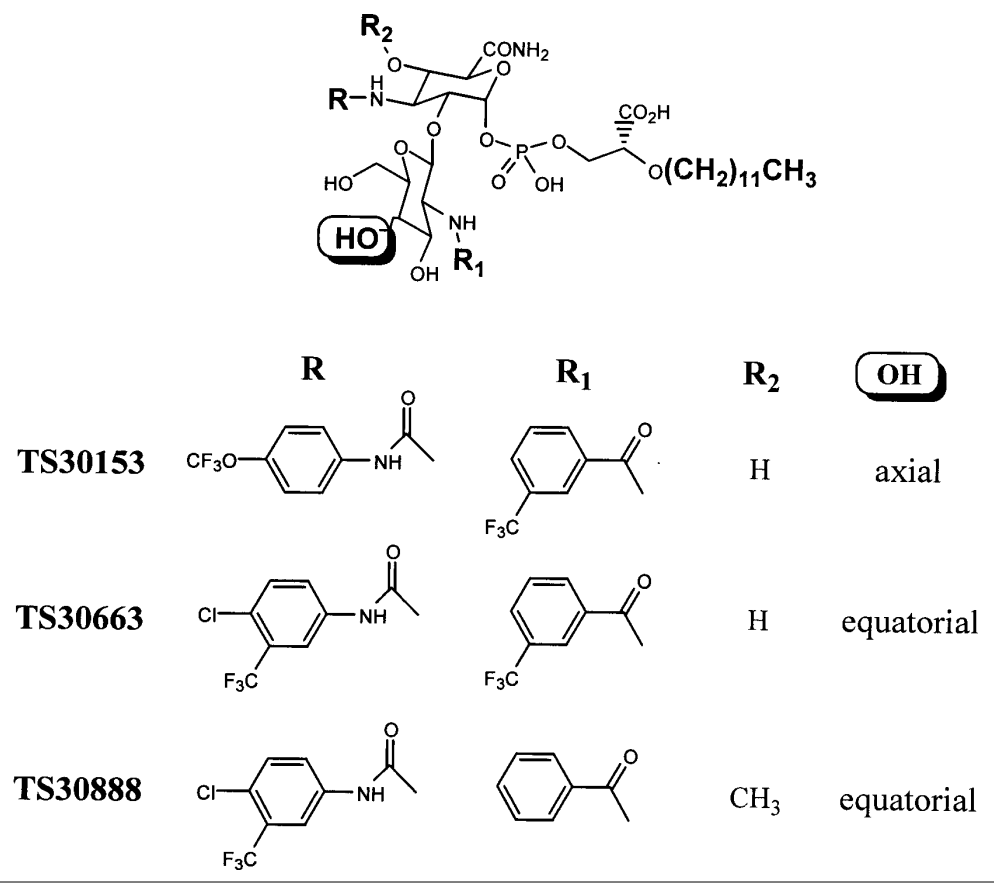

Fig. 2. Structure of the synthetic disaccharide analogues based on the moenomycin core structure.

activity on the supersensitive Esc. coli strain. They were at least 10-20-fold more active than the moenomycin disaccharide degradation product (TS0514), although they were two orders of magnitude less potent than moenomycin itself. Analogues TS30153 and TS30663 are less potent (2-16-fold) than vancomycin on vancomycin-sensitive Gram-positive bacteria, but they maintain their efficacy and potency on vancomycinresistant bacteria (Table 1). The disaccharide analogues were also active on Ent. faecium ATCC 49624 (Table 1), a naturally occurring isolate that is resistant to moenomycin. Thus, derivatization of the modified moenomycin disaccharide core and attachment of a less complex lipid chain led to molecules with a novel spectrum of antibacterial activity.

\section{Bactericidal activity of moenomycin and disaccharide analogues}

Our studies revealed that moenomycin had differential bactericidal activity on Gram-negative and Gram-positive bacteria. Moenomycin is bactericidal to Esc. coli and will cause rapid cell lysis (van Heijenoort et al., 1987). Killing was also observed in the absence of lysis when $\mathrm{Mg}^{2+}$ was added to cells to prevent autolysis. We obtained similar results with our hypersusceptible strain of Esc. coli (data not shown). The survival frequency was $3 \cdot 3 \times 10^{-4}$ and $2 \cdot 1 \times 10^{-5}$ in the presence and absence of $\mathrm{Mg}^{2+}$, respectively, $4 \mathrm{~h}$ after treatment with $0.25 \mu \mathrm{g}$ moenomycin $\mathrm{ml}^{-1}$ (10 times the MIC level of drug).

In contrast, moenomycin showed only slight bactericidal 


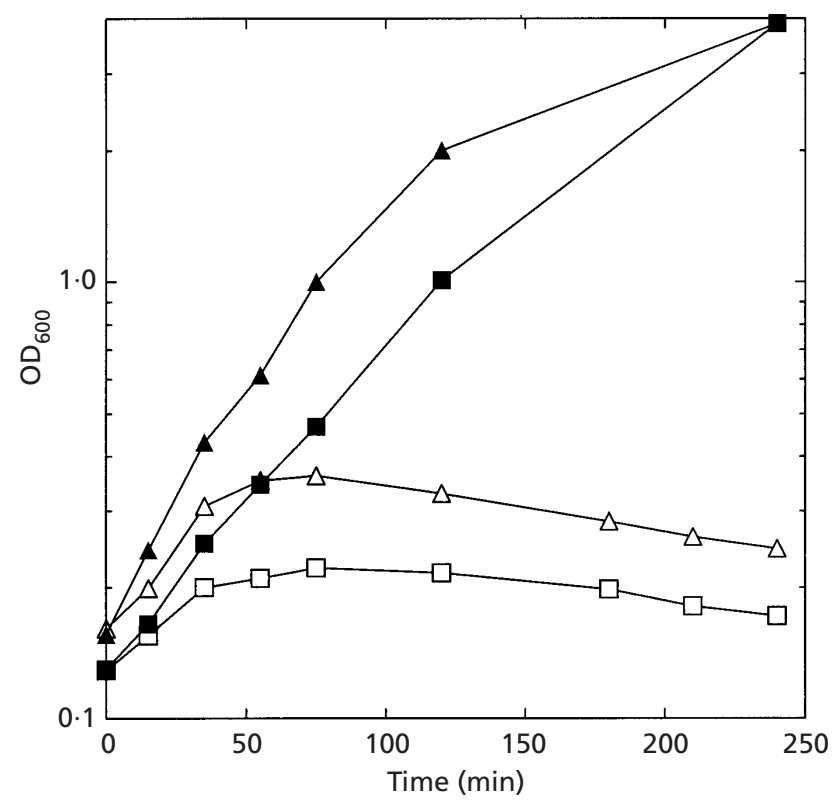

Fig. 3. Effect of moenomycin on the growth of Sta. epidermidis ATCC 12228 and Sta. aureus ATCC 29213. Cells were grown in BHI/CAA and moenomycin added to 10 times the MIC. The growth rate gradually decreased, followed by a slow decline in the $\mathrm{OD}_{600}$ values. Similar results were obtained at 100 times MIC, but with a slightly faster decline in the $O_{600}$ values. Sta. epidermidis ATCC 12228: control ( $\square$ ); moenomycin ( $\square$ ). Sta. aureus ATCC 29213: control (A); moenomycin $(\triangle)$.

activity on Gram-positive bacteria. Moenomycin gradually inhibited growth of Ent. faecalis at concentrations ranging from 4 to 600 times MIC, and the optical density gradually increased threefold by $4 \mathrm{~h}$ after drug addition (data not shown). Sta. aureus and Sta. epidermidis showed slightly faster growth shut-off occurring $1 \mathrm{~h}$ after treatment with moenomycin at 10 or 100 times the MIC, and the optical density declined slightly between 1 and $4 \mathrm{~h}$ post-drug addition (Fig. 3). The timing of growth shut-off was similar at 100 times MIC, but the decline in optical density was slightly faster (data not shown).

In addition to moenomycin being weakly bactericidal to Gram-positive bacteria, the degree of bactericidal activity was also dependent on the species tested. Less than $1 \log$ unit of killing occurred after $4 \mathrm{~h}$ when Ent. faecium strain RLA1 (Fig. 4b) or Ent. faecalis (not shown) were treated with up to 500 times the MIC of moenomycin. Similar data were obtained with Sta. aureus when treated with 10-100 times MIC of moenomycin (Fig. 4a and data not shown). We tested high levels of moenomycin to validate that the low level of killing was inherent to moenomycin, and not just dependent on the amount used. Three log units of killing occurred when Sta. epidermidis was treated with 100 times the MIC of moenomycin (Fig. 4a) and this was reduced to $2 \log$ units of killing at 10 times MIC (data not shown). In contrast, TS30663 (Fig. 4a) killed 4-6 log units when Grampositive bacteria were treated with four to eight times

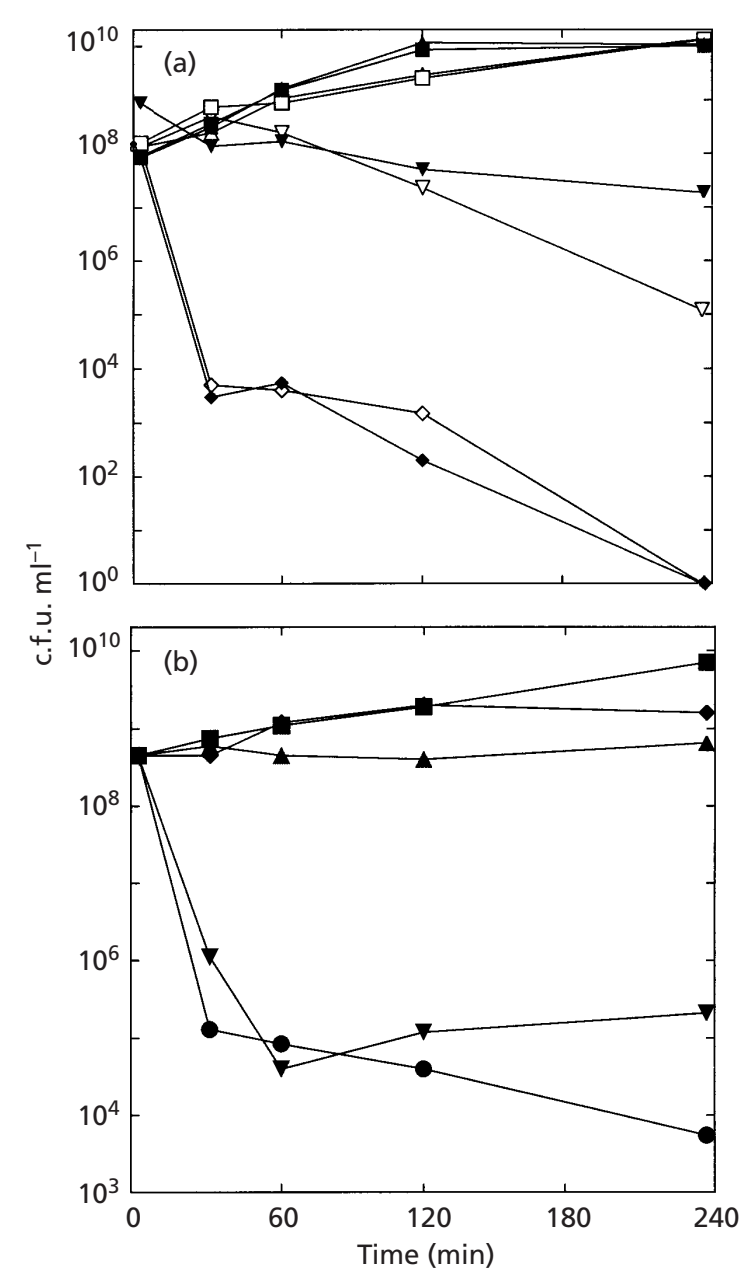

Fig. 4. Bactericidal effect of moenomycin and synthetic disaccharide analogues on Gram-positive bacteria. (a) Cells were grown in BHI/CAA and moenomycin added to 100 times MIC, or disaccharide analogues added to eight times MIC. c.f.u. were determined by plating serial dilutions at various times following drug addition. Sta. epidermidis ATCC 12228: control $(\square) ; 2.5 \%$ DMSO $(\triangle)$; moenomycin $(\nabla) ; \operatorname{TS} 30663(\diamond)$. S.

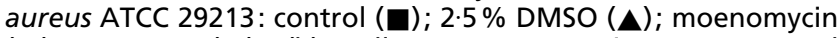
$(\boldsymbol{\nabla})$; TS30663 $(\diamond)$. (b) Cells were grown in BHI/CAA and moenomycin added to 100 times MIC of strain RLA1, or disaccharide analogues added to eight times MIC. c.f.u. were determined by plating serial dilutions at various times following drug addition. Ent. faecium RLA1: $2.5 \%$ DMSO (ם); moenomycin $(\boldsymbol{\Delta})$; TS30663 ( $\boldsymbol{\nabla})$; Ent. faecium strain ATCC 49624, which is naturally resistant to moenomycin: $2 \cdot 5 \%$ DMSO $(\diamond)$; TS30663 (๑).

MIC for 4 h. Similar results were obtained with TS30153 and TS30888 (data not shown). The multi-drug-resistant Ent. faecium strain RLA1 (Fig. 4b) and the vancomycinresistant Ent. faecalis strain CL5244 (not shown) were also killed 3-5 log units when treated with four to eight times MIC of the disaccharide analogue TS30663. Ent. faecium strain ATCC 49624 was resistant to moenomycin (Table 1) and thus not killed by moenomycin, but was killed by TS30663 (Fig. 4b).

Non-growing bacterial cells are characteristically re- 
Table 2. Effect of protein synthesis inhibition and moenomycin treatment on killing by disaccharide analogues

c.f.u. $\mathrm{ml}^{-1}$ were determined at time 0 and the first drug was added $\left(50 \mu \mathrm{g}\right.$ chloramphenicol ml ${ }^{-1}$, $20 \mu \mathrm{g}$ tetracycline $\mathrm{ml}^{-1}$ or $10 \mu \mathrm{g}$ moenomycin $\mathrm{ml}^{-1}$ ). After growth shut-off due to the first drug, cultures were diluted in medium (to $\mathrm{OD}_{600}=0 \cdot 1$ ) containing the same concentration of first drug and c.f.u. $\mathrm{ml}^{-1}$ were determined in triplicate. Challenge drug was then added (TS30153, TS30663) at 4-8 times MIC. c.f.u. $\mathrm{ml}^{-1}$ were determined again at $4 \mathrm{~h}$ after addition of challenge drug. Growing cells were also challenged with test drug (TS30153 and TS30663), $50 \mu \mathrm{g} \mathrm{ml}^{-1}$ at $\mathrm{OD}_{600}=0 \cdot 1$ for $4 \mathrm{~h}$, and survival frequency determined. Values in parentheses are from a repeat experiment.

\begin{tabular}{|lcc|}
\hline Drug treatment & Survival frequency* & Survival non-growing/growing \\
\hline Chloramphenicol & $1 \cdot 0$ & \\
Chloramphenicol plus TS30153 & $0 \cdot 81(0 \cdot 91)$ & $2 \cdot 7 \times 10^{4}\left(1 \cdot 1 \times 10^{4}\right)$ \\
Chloramphenicol plus TS30663 & $0 \cdot 52$ & $>5 \cdot 2 \times 10^{5}$ \\
Tetracycline & $1 \cdot 0$ & \\
Tetracycline plus TS30153 & $0 \cdot 26(0 \cdot 38)$ & \\
Tetracycline plus TS30663 & $0 \cdot 32$ & $>3 \cdot 9 \times 10^{3}\left(4 \cdot 7 \times 10^{4}\right)$ \\
Moenomycin & $1 \cdot 0$ & $>10^{4}\left(1 \cdot 4 \times 10^{4}\right)$ \\
Moenomycin plus TS30153 & $0 \cdot 57(1 \cdot 1)$ & \\
Moenomycin plus TS30663 & $0 \cdot 12$ & \\
TS30153 alone & $3 \cdot 0 \times 10^{-5}$ & \\
TS30663 alone & $<1 \cdot 0 \times 10^{-6}$ & \\
\hline
\end{tabular}

* The viable cell count after treatment with the first drug (growth shut-off) was normalized to 1.0 and survival frequency determined for treatment with the challenge drug.

Table 3. Inhibition of peptidoglycan synthesis

Values in parentheses are $95 \%$ confidence intervals from data for 2-10 separate experiments, using duplicate wells for each compound concentration in all experiments.

\begin{tabular}{|c|c|c|c|c|}
\hline \multirow[t]{2}{*}{ Compound } & \multicolumn{2}{|c|}{ In vitro peptidoglycan synthesis* } & \multicolumn{2}{|c|}{ In vivo peptidoglycan synthesis $\dagger$} \\
\hline & $\mathrm{IC}_{50}\left(\mu \mathrm{g} \mathrm{ml}^{-1}\right)$ & $\mathrm{IC}_{50}(\mu \mathrm{M})$ & $\mathrm{IC}_{50}\left(\mu \mathrm{g} \mathrm{ml}^{-1}\right)$ & $\mathrm{IC}_{50}(\mu \mathrm{M})$ \\
\hline TS30153 & $15 \cdot 2(9 \cdot 1-17 \cdot 4)$ & $14 \cdot 3$ & $9 \cdot 2(7 \cdot 2-11 \cdot 8)$ & $8 \cdot 6$ \\
\hline TS30888 & $6 \cdot 9(6 \cdot 3-7 \cdot 5)$ & $6 \cdot 7$ & $2 \cdot 8(2 \cdot 0-3 \cdot 8)$ & $2 \cdot 6$ \\
\hline TS30663 & $10 \cdot 6(8 \cdot 7-12 \cdot 8)$ & $9 \cdot 8$ & $3 \cdot 9(3 \cdot 6-4 \cdot 1)$ & $3 \cdot 8$ \\
\hline Moenomycin & $0.025(0 \cdot 017-0 \cdot 036)$ & $0 \cdot 0156$ & $>200$ & $>140$ \\
\hline Vancomycin & $5 \cdot 31(4 \cdot 44-6 \cdot 36)$ & $3 \cdot 66$ & $1 \cdot 30(1 \cdot 03-1 \cdot 63)$ & $0 \cdot 90$ \\
\hline
\end{tabular}

* Measured as incorporation of UDP- $\left[{ }^{14} \mathrm{C}\right] \mathrm{GlcNAc}$ into peptidoglycan using ether-permeabilized Esc. coli. Incorporation of label reached $5-10 \%$ and represented $3000-6000$ d.p.m. (50-100 Bq) in the control sample.

† Measured as incorporation of $\left[{ }^{14} \mathrm{C}\right]$ lysine into peptidoglycan in Ent. faecalis over the linear range of $60 \mathrm{~min}$. Control values were 15000-20000 d.p.m. (250-333 Bq).

sistant to killing by cell-wall synthesis inhibitors. Accordingly, stationary-phase cells were resistant to killing by the disaccharide analogues, yielding survival frequencies of $0 \cdot 18-0 \cdot 41$ that were $10^{3}-10^{5}$ greater than survival frequencies for growing cells (data not shown). In addition, the bactericidal activity of disaccharide analogues was abolished when bacteria were pretreated with tetracycline, chloramphenicol or moenomycin (Table 2). Tetracycline and chloramphenicol inhibited growth, though both caused minimal killing by themselves $(<1 \log$ unit). Bactericidal activity of the di- saccharide analogues was abolished in chloramphenicoland moenomycin-pretreated cells, and nearly abolished in tetracycline-pretreated cells by factors of $10^{3}-10^{5}$ compared to growing cells.

\section{Inhibition of peptidoglycan synthesis in permeabilized Esc. coli cells}

The disaccharide analogues TS30663, TS30153 and TS30888 all inhibited peptidoglycan synthesis in etherpermeabilized Esc. coli cells (Table 3) with $\mathrm{IC}_{50}$ values of 

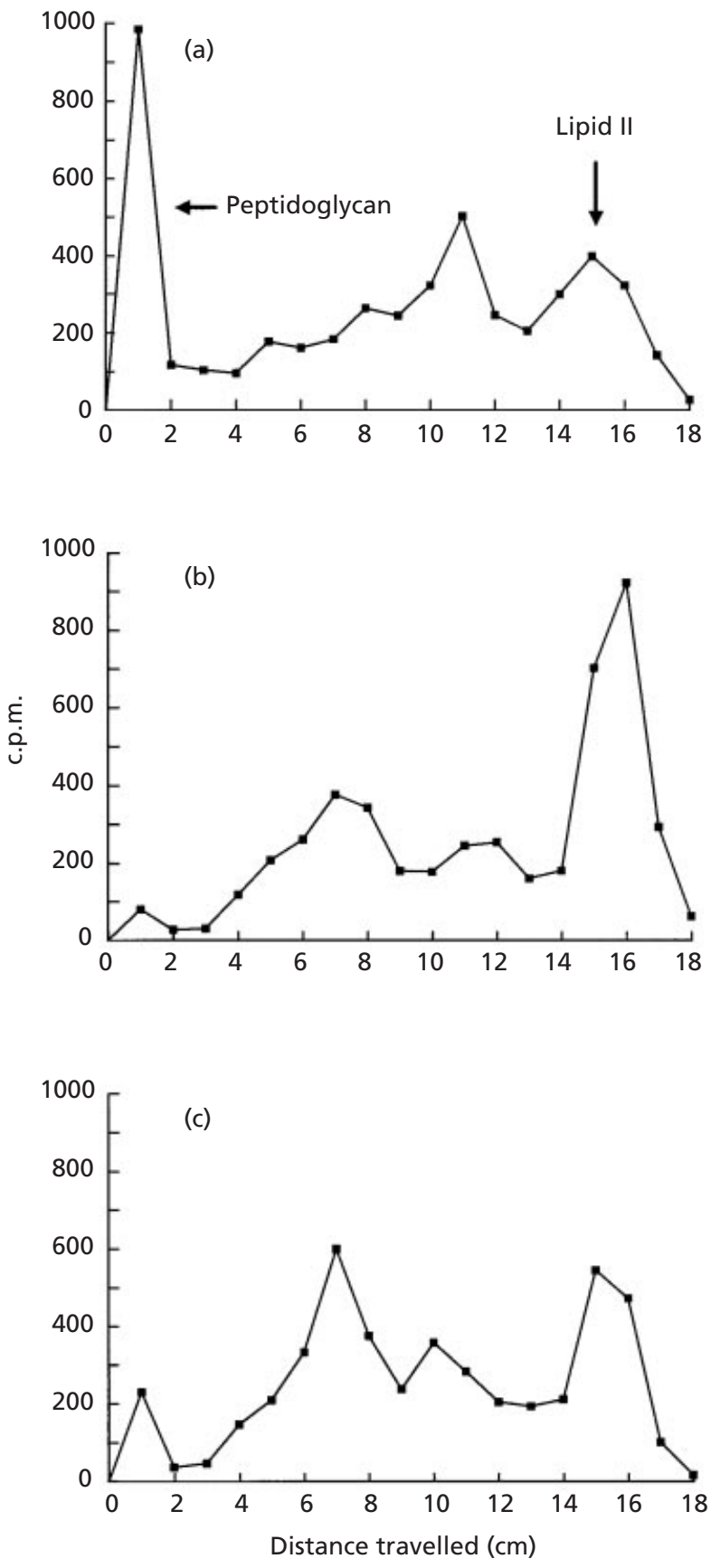

Fig. 5. Effect of moenomycin and disaccharide analogues on lipid II formation and peptidoglycan synthesis in Esc. coli. Bacterial membranes were incubated with UDP-MurNAcpentapeptide (biotinylated on lysine) and UDP- $\left[{ }^{14} \mathrm{C}\right] \mathrm{GlcNAc}$ to form lipid II and subsequent peptidoglycan (a). Lipid II was synthesized and accumulated in the presence of $10 \mu \mathrm{g}$ moenomycin $\mathrm{ml}^{-1}$, but inhibition of transglycosylation blocked peptidoglycan formation (b). Similarly, lipid II formation occurred in the presence of $100 \mu \mathrm{g}$ TS30153 $\mathrm{ml}^{-1}$, while peptidoglycan synthesis was inhibited (c). Reaction products were separated by ascending paper chromatography.

$10 \cdot 6,15 \cdot 2$ and $6.9 \mu \mathrm{g} \mathrm{ml}^{-1}$, respectively. This assay is sensitive to a range of known inhibitors (including moenomycin and vancomycin) of peptidoglycan syn-

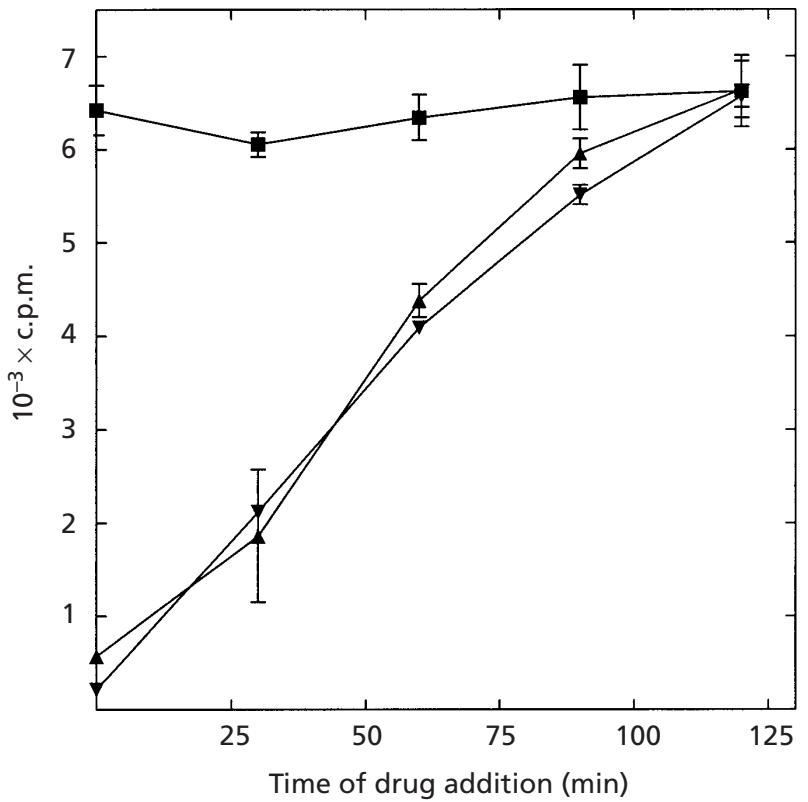

Fig. 6. Effect of disaccharide analogues on stability of peptidoglycan. Ether-permeabilized Esc. coli were incubated with UDP-MurNAc-pentapeptide and UDP- $\left[{ }^{14} \mathrm{C}\right] \mathrm{GICNAC}$, in the presence of test compound added at different times following initiation of the reaction. Samples were processed in triplicate and the amount of $\left[{ }^{14} \mathrm{C}\right] \mathrm{GICNAc}$ incorporated into peptidoglycan determined. The reaction was linear for $120 \mathrm{~min}$. Disaccharide analogues $\left(100 \mu \mathrm{g} \mathrm{ml}^{-1}\right)$ were added at $0,30,60$, 90 and $120 \mathrm{~min}$ following initiation of the reaction. All samples were terminated at $120 \mathrm{~min}$. Buffer controls showed a constant level of incorporation. Peptidoglycan made during the first 30, 60 or $90 \mathrm{~min}$ was stable during the remainder of the incubation, as the expected level of incorporation was observed. Values in the figure represent means $( \pm S E)$ of triplicate wells at each data point. Control (ם); TS30153 ( $\boldsymbol{\Delta})$; TS30888 ( $\boldsymbol{\nabla})$.

thesis (Table 3). Moenomycin is the most potent of these inhibitors on both a mass and molar basis with an $\mathrm{IC}_{50}$ of $0.025 \mu \mathrm{g} \mathrm{ml}^{-1}(0 \cdot 016 \mu \mathrm{M})$. The disaccharide analogues were 400-600-fold (based on mass and molarity, respectively) less potent compared to moenomycin in their ability to inhibit peptidoglycan synthesis in ether-treated Esc. coli. However, the disaccharide analogues were of the same relative potency as vancomycin in this in vitro system. In all cases, complete inhibition of peptidoglycan synthesis at high doses of drug was documented by spotting a sample of the reaction mix for paper chromatography (Anderson et al., 1966) and determining the amount of radioactivity in peptidoglycan present at the origin.

\section{Inhibition of cell-wall synthesis in Ent. faecalis}

The disaccharide analogues also inhibited cell-wall synthesis in intact Ent. faecalis cells (Table 3) at concentrations near their MIC values. Vancomycin was used as a control compound that also inhibited incorporation of $\left[{ }^{14} \mathrm{C}\right]$ lysine into cell walls. The disaccharide analogues were within 3-10-fold of the activity 


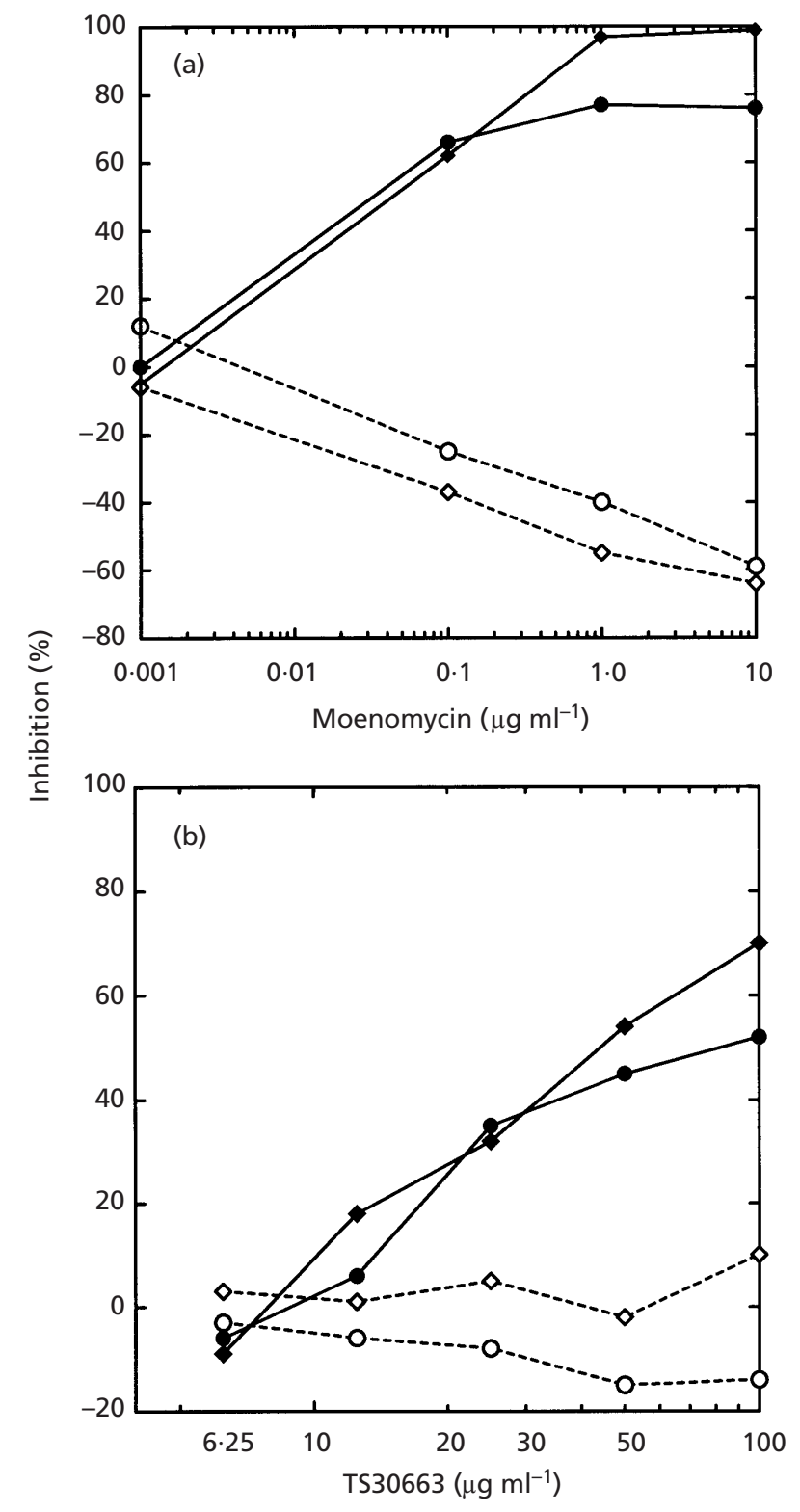

Fig. 7. Inhibition of mature and immature peptidoglycan and accumulation of lipid intermediates in Esc. coli. Increasing concentrations of moenomycin (a) or TS30663 (b) were added to in vitro peptidoglycan synthesis reactions containing UDP-[ $\left[{ }^{14} \mathrm{C}\right] \mathrm{GICNAC}$ and UDP-MurNAc-pentapeptide with $1 \mathrm{mg}$ penicillin $\mathrm{ml}^{-1}$ [to measure immature (non crosslinked) peptidoglycan] or without penicillin (for mature peptidoglycan). Lipid intermediates were extracted with 1butanol:6 M pyridinium acetate $(2: 1 \mathrm{v} / \mathrm{v})$. The mean value of triplicate data points is given. Control peptidoglycan synthesis $(100 \%)$ is equivalent to $18-25$ kc.p.m. for mature, and 59 kc.p.m. for immature peptidoglycan, respectively. Solventextractable c.p.m. (lipid II and intermediates) ranged from 5 to 10 kc.p.m. in controls. , immature peptidoglycan and $\bigcirc$, accumulated lipid intermediates; $\diamond$, mature peptidoglycan and $\diamond$, accumulated lipid intermediates.

of vancomycin on both a mass and molar basis in this assay (Table 3). Surprisingly, moenomycin itself did not show inhibition even when tested at $200 \mu \mathrm{g} \mathrm{ml}^{-1}$.

\section{Lipid II and peptidoglycan synthesis using Esc. coli membranes}

Neither moenomycin, TS30153, TS30663, nor TS30888 inhibited formation of lipid II from UDP-MurNAcpentapeptide and UDP-GlcNAc in an assay designed to measure only lipid II synthesis (see Branstrom et al., 2000b; data not shown). By contrast, in the same assay, tunicamycin (an inhibitor of MraY) inhibited lipid II formation by $50 \%$ at $1 \mu \mathrm{g} \mathrm{ml}^{-1}$, as expected. We confirmed that peptidoglycan was in fact formed by Esc. coli membranes from biotinylated UDP-MurNAc-pentapeptide during a $2 \mathrm{~h}$ incubation (Fig. 5a). As expected, moenomycin, at 400 times its $\mathrm{IC}_{50}$, inhibited peptidoglycan formation and caused accumulation of lipid II (Fig. 5b). TS30153 also inhibited peptidoglycan formation at six times its $\mathrm{IC}_{50}$ (highest concentration testable), but not formation of lipid II (Fig. 5c), and no accumulation of lipid II relative to controls was observed. Similar results were obtained for TS30888 and TS30663 (data not shown). Lipid II was identified by mobility, incorporation of labelled GlcNAc and the presence of biotin (from UDP-MurNAc-pentapeptide) as assessed by capture with Softlink avidin resin (not shown).

\section{Direct analysis of inhibition of lipid II polymerization into peptidoglycan}

Inhibition of transglycosylation was monitored by following conversion of endogenous, radiolabelled lipid II into peptidoglycan. Moenomycin was a potent inhibitor with an $\mathrm{IC}_{50}$ of $9.6 \mathrm{ng} \mathrm{ml}^{-1}(95 \%$ confidence interval $=8 \cdot 2-11 \cdot 2 \mathrm{ng} \mathrm{ml}^{-1}$ ). TS30663 also gave a typical sigmoidal concentration-response curve in the assay and an $\mathrm{IC}_{50}$ value of $27 \cdot 8 \mu \mathrm{g} \mathrm{ml}^{-1} \quad(95 \%$ confidence interval $\left.=20 \cdot 33-38 \cdot 04 \mu \mathrm{g} \mathrm{ml}{ }^{-1}\right) . \mathrm{IC}_{50}$ values for TS30153 and TS30888 were estimated at 40 and $15 \mu \mathrm{g} \mathrm{ml}^{-1}$, respectively, by single point analysis (data not shown).

\section{Analysis of potential peptidoglycan degradation}

The disaccharide analogues inhibited incorporation into peptidoglycan of radiolabelled $\left[{ }^{14} \mathrm{C}\right] \mathrm{GlcNAc}$ from UDPGlcNAc (Table 3). This could be due to either inhibition of peptidoglycan synthesis, or stimulation of peptidoglycan degradation. We thus examined the stability of newly synthesized peptidoglycan made during various time periods over the course of the $2 \mathrm{~h}$ incubation. Peptidoglycan synthesis was allowed to occur for various times, and then disaccharide inhibitors were added. Peptidoglycan made prior to disaccharide addition, even during the first $30 \mathrm{~min}$, was stable during the remainder of the $2 \mathrm{~h}$ incubation (Fig. 6). These data show that the disaccharide analogues inhibit formation of peptidoglycan, but do not stimulate its degradation.

\section{Inhibition of mature and immature peptidoglycan in Esc. coli}

Like moenomycin, TS30663 inhibited synthesis of both mature and immature peptidoglycan (Fig. 7), consistent with inhibition at the transglycosylation stage. Whereas 
moenomycin caused a 50\% increase in butanolextractable lipid II, only slight accumulation of lipid intermediates occurred with TS30663 treatment when penicillin was included to inhibit cross-linking of peptidoglycan.

\section{C. albicans growth and glucan synthesis}

Growth of C. albicans strain CCH442 was not altered by $50 \mu \mathrm{g}$ disaccharide analogues $\mathrm{ml}^{-1}$ (data not shown). In addition, disaccharide analogues failed to inhibit 1,3$\beta$-glucan synthesis by microsomes from the same strain, when tested at $50 \mu \mathrm{g} \mathrm{ml}^{-1}$. Thus, the antimicrobial effects of these novel disaccharide analogues appeared specific for bacterial cell-wall synthesis.

\section{In vitro cell viability}

The $\mathrm{LD}_{50}$ for cytotoxicity in three mammalian cell lines (NIH3T3, HL-60 and HBL-100) averaged $15 \mu \mathrm{g} \mathrm{ml}^{-1}$ for TS30663 and $>50 \mu \mathrm{g} \mathrm{ml}^{-1}$ for both TS30888 and TS30153. A concentration of $100 \mu \mathrm{g}$ moenomycin $\mathrm{ml}^{-1}$ failed to exhibit significant effects on viability in any of these cell lines (data not shown). The differential antimicrobial effects that were observed at MIC levels for moenomycin versus novel disaccharide analogues reported in the present studies are, therefore, unlikely to be due to non-specific cytotoxicity.

\section{DISCUSSION}

Moenomycin is one of the few known inhibitors of the essential transglycosylation reaction catalysing polymerization of lipid II into bacterial peptidoglycan. Moenomycin has a broad spectrum of activity against Gram-positive bacteria, and is active in vivo in mouse models of bacterial infection (von Wasielewski et al., 1965). However, moenomycin itself has no clinical utility because it is poorly absorbed. It shows low systemic toxicity in animals and is used as an animal feed 'growth promoter' under the Hoechst trademark Flavomycin (Huber, 1979). The minimal structural requirements for antibacterial activity consist of a trisaccharide linked to a $\mathrm{C}_{25}$ hydrophobic tail, moenocinol, via a phosphoric acid diester and a glycerol acid unit, with the disaccharide (Fig. 2) being nearly devoid of antibacterial activity (El-Abadla et al., 1999). Essential components of the basic moenomycin structure likely interact with the donor or acceptor sites on the transglycosylase enzyme, thus inhibiting enzyme interaction with the normal lipid II substrate and/or nascent lipid-linked peptidoglycan. However, most of the studies investigating the mode of action of moenomycin on bacteria were conducted with the Gramnegative bacterium Esc. coli.

A programme was initiated based on synthesis of analogues of the moenomycin disaccharide structure (Kakarla et al., 1999; Sofia et al., 1999). Our rationale was that creating new sites of interaction with amino acid residues adjacent to the active site on a target enzyme could enhance even the weak activity reported for disaccharide analogues related to the moenomycin core structure (El-Abadla et al., 1999). Simplified lipids were also included in the synthetic scheme in place of the $\mathrm{C}_{25}$ moenocinol. Combinatorial chemistry, using synthetic strategies developed in our laboratory (Sofia et al., 1999; Kakarla et al., 1999) was used to explore chemical modification of the disaccharide core. Several active compounds were identified and three (TS30153, TS30663 and TS30888) were investigated in detail.

The three disaccharide analogues studied all possess antibacterial activity against Gram-positive bacteria, including strains resistant to vancomycin, with MIC values ranging from 3 to $12 \mu \mathrm{g} \mathrm{ml}^{-1}$. Since the moenomycin disaccharide degradation product (TS0514) is inactive as an antibacterial agent, our data demonstrate that appropriate derivatization of the $\mathrm{E}$ and $\mathrm{F}$ units can lead to antibacterial agents active on both sensitive and resistant bacteria. These disaccharide analogues are active on vancomycin-resistant strains and are nearly as potent as vancomycin on vancomycin-sensitive strains.

Almost all the data in the literature pertaining to inhibition of transglycosylase activity by moenomycin and its physiological consequences on bacteria, comes from the study of Esc. coli (Hara \& Suzuki, 1984; Kohlrausch \& Holtje, 1991a; Tamura et al., 1980; van Heijenoort et al., 1978, 1987; van Heijenoort \& van Heijenoort, 1980). Moenomycin is rapidly bactericidal to growing Esc. coli, resulting in bacterial lysis and cell death, although lysis is not required for loss of viability. In contrast, our data reveal that the bactericidal activity of moenomycin is limited for Gram-positive bacteria. Only 1-2 log units of killing occurred when Grampositive bacteria were treated with 5-10 times the MIC value of moenomycin. Killing was increased to $3 \mathrm{log}$ units when the most sensitive species, Sta. epidermidis, was treated with 100 times the MIC of moenomycin. In contrast, the disaccharide analogues killed 3-6 log units when Gram-positive bacteria were treated with four to eight times the MIC. Thus, modifications to the disaccharide core resulted in the discovery of novel bactericidal analogues contrasting with the parent compound that had only bacteriostatic effects in Grampositive bacteria.

Our data revealed that disaccharide analogues blocked peptidoglycan synthesis in ether-permeabilized Esc. coli at some point between the synthesis of lipid II and its polymerization into peptidoglycan by transglycosylation. This in vitro system requires the concerted action of MraY, MurG, lipid II translocation and recycling, and polymerization of lipid II into peptidoglycan. Evidence supporting inhibition of the transglycosylation stage by the synthetic disaccharide analogues is as follows. Neither the disaccharide analogues nor moenomycin inhibited lipid II synthesis in a system that depended on the functioning of MraY and MurG. However, both moenomycin and the disaccharide analogues did inhibit conversion of lipid II into peptidoglycan. Disaccharide analogues and moenomycin in- 
hibited synthesis of both mature and immature peptidoglycan, data consistent with inhibition at the transglycosylase stage. However, the disaccharide analogues caused less accumulation of lipid II than moenomycin. In addition, stimulation of peptidoglycan degradation was ruled out, since peptidoglycan made during various time periods in ether permeabilized Esc. coli was stable following addition of the disaccharide inhibitors. Thus, one may conclude that the site of inhibition is between lipid II formation and its polymerization into peptidoglycan via the transglycosylation process.

The synthetic disaccharide analogues target cell-wall synthesis in vivo, in intact Gram-positive bacteria, as assessed by both direct and indirect experimental results. They all inhibited incorporation of lysine into cell-wall material in intact Ent. faecalis with $\mathrm{IC}_{50}$ values within twofold of their respective MIC values on the same strain. In addition, the disaccharide analogues were bactericidal only to actively growing cells. Stationaryphase cells and cells pretreated with protein synthesis inhibitors or moenomycin were resistant to the bactericidal effects of the disaccharide analogues. Such differential killing is indicative of cell-wall synthesis inhibitors. Although little is known about the stringent response in Gram-positive bacteria, our data indicate that protein synthesis may be required for killing caused by the disaccharide analogues. Disaccharide analogues did not inhibit growth of C. albicans $\mathrm{CCH} 442$, or synthesis of 1,3- $\beta$-glucan from microsomes prepared from this strain (data not shown). The glucan-synthesis complex is known to be sensitive to agents which nonspecifically perturb membrane structure (Goldman et al., 1995; Ko et al., 1994). Testing for overt cytotoxicity at concentrations well above the MIC in several mammalian cell lines suggests that these novel compounds (and moenomycin itself) are unlikely to induce nonspecific bacterial cell killing.

Our data are consistent with the following hypotheses and current base of knowledge regarding bacterial transglycosylases and their inhibition by moenomycin. Moenomycin is not a universal transglycosylase inhibitor, since it does not inhibit the monofunctional glycosyltransferase from Esc. coli (Di Berardino et al., 1996; Hara \& Suzuki, 1984), or the transglycosylase activity from Micrococcus luteus (Park \& Matsuhashi, 1984). Thus one would expect differential effects on bacteria depending on (a) the repertoire of transglycosylases inhibited, (b) the degree of inhibition and (c) the physiological consequences of inhibition. The pronounced bactericidal activity and subsequent rapid lysis of Esc. coli following treatment with moenomycin might result from inhibition of the transglycosylase activity of PBP1A and PBP1B, but it may also inhibit other transglycosylase enzymes such as PBP1C (Schiffer \& Holtje, 1999). Our data are consistent with the hypothesis that these synthetic disaccharide analogues of moenomycin target specific components of the transglycosylation process in Gram-positive bacteria in a unique manner not shared by the parent compound, moenomycin. Perhaps moenomycin inhibits an essential transglycosylase activity in Gram-positive bacteria, but one that accounts for only a minor fraction of the total peptidoglycan. Given the complexity of the interactions between the biosynthetic components involved in peptidoglycan synthesis (Holtje, 1996a, b, 1998; Koch, 1998; Vollmer et al., 1999; von Rechenberg et al., 1996), further work will be required to understand the physiological consequences of inhibition of the transglycosylation process by different inhibitors. We are currently using these and other synthetic disaccharide analogues to clarify some of these processes.

\section{ACKNOWLEDGEMENTS}

The authors wish to thank Drs Nicole Hatzenbuhler, Dashan Liu and Ramesh Kakarla for synthesis and purification of the novel moenomycin-based disaccharides and degradation products reported in the text. We also thank Dr Helena Axelrod for her guidance and contributions during the early part of this project.

\section{REFERENCES}

Adam, M., Fraipont, C., Rhazi, N. \& 8 other authors (1997). The bimolecular G57-V577 polypeptide chain of the class B penicillinbinding protein 3 of Escherichia coli catalyzes peptide bond formation from thiolesters and does not catalyze glycan chain polymerization from the lipid II intermediate. J Bacteriol 179, 6005-6009.

Allen, N. E., Hobbs, J. N., Jr, Richardson, J. M. \& Riggin, R. M. (1992). Biosynthesis of modified peptidoglycan precursors by vancomycin-resistant Enterococcus faecium. FEMS Microbiol Lett 77, 109-115.

Allen, N. E., Hobbs, J. N., Jr \& Nicas, T. I. (1996). Inhibition of peptidoglycan biosynthesis in vancomycin-susceptible and -resistant bacteria by a semisynthetic glycopeptide antibiotic. Antimicrob Agents Chemother 40, 2356-2362.

Anderson, J. S., Meadow, P. M., Haskin, M. A. \& Strominger, J. L. (1966). Biosynthesis of the peptidoglycan of bacterial cell walls. I. Utilization of uridine diphosphate acetylmuramyl pentapeptide and uridine diphosphate acetylglucosamine for peptidoglycan synthesis by particulate enzymes from Staphylococcus aureus and Micrococcus lysodeikticus. Arch Biochem Biophys 116, 487-515.

Billot-Klein, D., Shlaes, D., Bryant, D., Bell, D., Legrand, R., Gutmann, L. \& van Heijenoort, J. (1997). Presence of UDP-Nacetylmuramyl-hexapeptides and -heptapeptides in enterococci and staphylococci after treatment with ramoplanin, tunicamycin, or vancomycin. J Bacteriol 179, 4684-4688.

Branstrom, A. A., Midha, S. \& Goldman, R. C. (2000a). In situ assay for identifying inhibitors of bacterial transglycosylase. FEMS Microbiol Lett 191, 187-190.

Branstrom, A. A., Midha, S., Longley, C. B., Han, K., Baizman, E. R. \& Axelrod, H. R. (2000b). Assay for identification of inhibitors specific for bacterial MraY translocase and MurG transferase. Anal Biochem 280, 315-319.

Di Berardino, M., Dijkstra, A., Stuber, D., Keck, W. \& Gubler, M. (1996). The monofunctional glycosyltransferase of Escherichia coli is a member of a new class of peptidoglycan-synthesising enzymes. FEBS Lett 392, 184-188.

El-Abadla, N., Lampilis, M., Hennig, L., Findeisen, M., Welzel, P., Muller, D., Markus, A. \& van Heijenoort, J. (1999). Moenomycin A : the role of the methyl group in the moenuronamide unit and a general discussion of structure-activity relationships. Tetrabedron 55, 699-722. 
Frost, D. J., Brandt, K., Capobianco, J. \& Goldman, R. (1994). Characterization of $(1,3)-\beta$-glucan synthase in Candida albicans: microsomal assay from the yeast or mycelial morphological forms and a permeabilized whole-cell assay. Microbiology 140, 2239-2246.

Ge, M., Chen, Z., Onishi, H. R., Kohler, J., Silver, L. L., Kerns, R., Fukuzawa, S., Thompson, C. \& Kahne, D. (1999). Vancomycin derivatives that inhibit peptidoglycan biosynthesis without binding D-Ala-D-Ala. Science 284, 507-511.

Goffin, C. \& Ghuysen, J.-M. (1998). Multimodular penicillinbinding proteins: an enigmatic family of orthologs and paralogs. Microbiol Mol Biol Rev 62, 1079-1093.

Goldman, R. C., Frost, D. J., Capobianco, J. O., Kadam, S., Rasmussen, R. R. \& Abad-Zapatero, C. (1995). Antifungal drug targets: Candida secreted aspartyl protease and fungal wall betaglucan synthesis. Infect Agents Dis 4, 228-247.

Hara, H. \& Suzuki, H. (1984). A novel glycan polymerase that synthesizes uncross-linked peptidoglycan in Escherichia coli. FEBS Lett 168, 155-160.

van Heijenoort, Y. \& van Heijenoort, J. (1980). Biosynthesis of the peptidoglycan of Escherichia coli K-12: properties of the in vitro polymerization by transglycosylation. FEBS Lett 110, 241-244.

van Heijenoort, Y., Derrien, M. \& van Heijenoort, J. (1978). Polymerization by transglycosylation in the biosynthesis of the peptidoglycan of Escherichia coli $\mathrm{K}-12$ and its inhibition by antibiotics. FEBS Lett 89, 141-144.

van Heijenoort, Y., Leduc, M., Singer, H. \& van Heijenoort, J. (1987). Effects of moenomycin on Escherichia coli. I Gen Microbiol 133, 667-674.

van Heijenoort, Y., Gomez, M., Derrien, M., Ayala, J. \& van Heijenoort, J. (1992). Membrane intermediates in the peptidoglycan metabolism of Escherichia coli: possible roles of PBP $1 \mathrm{~b}$ and PBP 3. J Bacteriol 174, 3549-3557.

Holtje, J. V. (1996a). A hypothetical holoenzyme involved in the replication of the murein sacculus of Escherichia coli. Microbiology 142, 1911-1918.

Holtje, J. V. (1996b). Molecular interplay of murein synthases and murein hydrolases in Escherichia coli. Microb Drug Resist 2, 99-103.

Holtje, J. V. (1998). Growth of the stress-bearing and shapemaintaining murein sacculus of Escherichia coli. Microbiol Mol Biol Rev 62, 181-203.

Huber, G. (1979). Moenomycin and related phosphoruscontaining antibiotics. In Antibiotics, vol. 5, part 1, p. 135. Edited by F. E. Hahn. New York: Springer.

Ikeda, M., Wachi, M. \& Matsuhashi, M. (1992). The $m u r G$ gene of the Escherichia coli chromosome encoding UDP-N-acetylglucosamine: undecaprenyl-pyrophosphoryl-N-acetylmuramoylpentapeptide $\mathrm{N}$-acetylglucosaminyl transferase. J Gen Appl Microbiol 38, 53-62.

Ishino, F. \& Matsuhashi, M. (1981). Peptidoglycan synthetic enzyme activities of highly purified penicillin-binding protein 3 in Escherichia coli: a septum-forming reaction sequence. Biochem Biophys Res Commun 101, 905-911.

Kakarla, R., Ghosh, M., Anderson, J. A., Dulina, R. G. \& Sofia, M. J. (1999). Expeditious route to $F$ unit building blocks of moenomycin A. Tetrahedron Lett 40, 5-8.

Ko, Y. T., Frost, D. J., Ho, C. T., Ludescher, R. D. \& Wasserman, B. P. (1994). Inhibition of yeast $(1,3)-\beta$-glucan synthase by phospholipase A2 and its reaction products. Biochim Biophys Acta $1193,31-40$.
Koch, A. L. (1998). The three-for-one model for gram-negative wall growth: a problem and a possible solution. FEMS Microbiol Lett 162, 127-134.

Kohlrausch, U. \& Holtje, J. V. (1991a). Analysis of murein and murein precursors during antibiotic-induced lysis of Escherichia coli. J Bacteriol 173, 3425-3431.

Kohlrausch, U. \& Holtje, J. V. (1991b). One-step purification procedure for UDP-N-acetylmuramyl-peptide murein precursors from Bacillus cereus. FEMS Microbiol Lett 62, 253-257.

Lai, M. H. \& Kirsch, D. R. (1996). Induction signals for vancomycin resistance encoded by the vanA gene cluster in Enterococcus faecium. Antimicrob Agents Chemother 40, 1645-1648.

Mani, N., Sancheti, P., Jiang, Z. D. \& 8 other authors (1998). Screening systems for detecting inhibitors of cell wall transglycosylation in Enterococcus: cell wall transglycosylation inhibitors in Enterococcus. J Antibiot 51, 471-479.

Matsuhashi, M., Ishino, F., Nakagawa, J., Mitsui, K., NakajimaIijima, S. \& Tamaki, S. (1981). Enzymatic activities of penicillinbinding protiens of Escherichia coli and their sensitivities to $\beta$ lactam antibiotics. In $\beta$-Lactam Antibiotics, pp. 169-184. Edited by M. Salton \& G. D. Shockman. New York: Academic Press.

Men, H., Park, P., Ge, M. \& Walker, S. (1998). Substrate synthesis and activity assay for MurG. J Am Chem Soc 120, 2484-2485.

Mirelman, D., Yashouv-Gan, Y. \& Schwarz, U. (1976). Peptidoglycan biosynthesis in a thermosensitive division mutant of Escherichia coli. Biochemistry 15, 1781-1790.

Park, W. \& Matsuhashi, M. (1984). Staphylococcus aureus and Micrococcus luteus peptidoglycan transglycosylases that are not penicillin-binding proteins. J Bacteriol 157, 538-544.

von Rechenberg, M., Ursinus, A. \& Holtje, J. V. (1996). Affinity chromatography as a means to study multienzyme complexes involved in murein synthesis. Microb Drug Resist 2, 155-157.

Sampson, B. A., Misra, R. \& Benson, S. A. (1989). Identification and characterization of a new gene of Escherichia coli K-12 involved in outer membrane permeability. Genetics 122, 491-501.

Schiffer, G. \& Holtje, J.-V. (1999). Cloning and characterization of PBP 1C, a third member of the multimodular class A penicillinbinding proteins of Escherichia coli. J Biol Chem 274, 32031-32039.

Sofia, M. J., Allanson, N., Hatzenbuhler, N. \& 23 other authors (1999). Discovery of novel disaccharide antibacterial agents using a combinatorial library approach. J Med Chem 42, 3193-3198.

Tamura, T., Suzuki, H., Nishimura, Y., Mizoguchi, J. \& Hirota, Y. (1980). On the process of cellular division in Escherichia coli: isolation and characterization of penicillin-binding proteins $1 \mathrm{a}$, 1b, and 3. Proc Natl Acad Sci U S A 77, 4499-4503.

Vollmer, W., von Rechenberg, M. \& Holtje, J. V. (1999). Demonstration of molecular interactions between the murein polymerase PBP1B, the lytic transglycosylase MltA, and the scaffolding protein MipA of Escherichia coli. J Biol Chem 274, 6726-6734.

Vosberg, H. P. \& Hoffmann-Berling, H. (1971). DNA synthesis in nucleotide-permeable Escherichia coli cells. I. Preparation and properties of ether-treated cells. J Mol Biol 58, 739-753.

von Wasielewski, E., Muschaweck, R. \& Schutze, E. (1965). Moenomycin, a new antibiotic. 3. Biological properties. Antimicrob Agents Chemother 5, 743-748.

Received 23 May 2000; revised 8 August 2000; accepted 13 September 2000. 